\title{
Ao Prof. Jamary Oliveira, a gratidáo e o reconhecimento da Escola de Música da UFBA
}

\author{
José Maurício Brandão \\ Universidade Federal da Bahia | Orcid: 0000-0003-2775-1587 \\ Diretor da Escola de Música da UFBA
}

Neste ano de 2020, um ano atípico envolvendo uma pandemia e seus desdobramentos, que nos obrigou aos exercícios da paciência, da serenidade e da reinvenção, deixamos de contar com a companhia do querido Prof. Jamary Oliveira. Não digo que o perdemos, porque seu legado pessoal e institucional como professor, compositor, pesquisador e orientador manter-se-ão impregnados nas paredes da Escola de Música e mundo afora, dentro de cada um dos tantos colegas que tiveram a felicidade e a honra de aprender com ele. Nestas poucas linhas - em nome da Escola de Música da UFBA - ratifico nosso pleito de gratidão por toda a dedicação e tantas contribuições que Jamary Oliveira devotou à nossa Escola.

Jamary nasceu em Saúde (município situado na regiâo Centro-Norte do estado da Bahia, a $353 \mathrm{Km}$ da capital) a 21 de março de 1944. Em Salvador, Jamary ingressou nos Seminários de Música da Universidade da Bahia (atual Escola de Música da UFBA), graduando-se em Composição em 1969 na classe do Prof. Ernst Widmer. Seus estudos musicais incluíram a flauta, a viola, a tuba, a teoria da música e a composição. Na UFBA, em 1966 atuou na fundação do Grupo de Compositores da Bahia, e teve contato, através de cursos de extensão, com nomes como Edgar Willems, Edino Krieger, Ingmar Gruemauer e Peter Maxwell Davies. Integrou ainda o Conjunto Experimental de Percussão, e teve participação muito ativa nos Festivais de Música Nova e nos Seminários Internacionais de Música da UFBA.

Nos anos 70 do século passado, iniciou atividades de pesquisa que resultaram em diversos softwares para uso em música. No campo da pesquisa, atividade que desenvolveu continuamente desde então, foi pesquisador sênior do CNPq. Em 1979 concluiu Mestrado em Composição na Brandeis University (Massachusetts, USA), e em 1986 o Doutorado em Composição pela University of Texas at Austin (Texas, USA). 
Na Escola de Música da UFBA atuou como docente de 1966 até sua aposentadoria em 1994, mantendo-se posteriormente em atividade como docente colaborador do Programa de Pós Graduação em Música da UFBA (PPGMUS-UFBA), do qual também foi membro fundador. Foi Chefe do Departamento de Composiçáo, Literatura e Estruturaçáo Musical, Coordenador do Colegiado do Curso de Composição e Regência, Presidente da Câmara de Graduação e Assessor do Reitor da UFBA para assuntos de Pesquisa e Pós-Graduação.

Foi membro fundador da Sociedade Brasileira de Música Contemporânea, e em 1994 foi eleito membro da Academia Brasileira de Música. No início dos anos 90 do século passado, foi peça fundamental na estruturação da pós-graduação em Música no Brasil. Neste campo, atuou como presidente da Associação Nacional de Pesquisa e Pós-Graduação em Música (ANPPOM), da qual também foi membro fundador, e representante da área de Música no CNPq. Também foi membro da Academia de Ciências da Bahia, integrando o seu corpo representantivo das Artes, desde sua fundação em 2010.

Autocrítico e inventivo, o compositor Jamary Oliveira sempre evitou aderir a "credos" composicionais fechados e dogmáticos ${ }^{1}$. O experimental como motivador e um forte interesse pelo contraponto sempre permearam suas obras. Em um frase podemos mergulhar no pensamento de Jamary: "A complexidade demonstra o conhecimento técnico, a simplicidade o domínio deste conhecimento." ${ }^{2}$ Suas obras, que envolvem música eletroacústica, música vocal, orquestral e de câmara e muitas obras para piano, primam pela concisão, equilíbrio e refinamento de elaboração. Como ele mesmo definia, uma obra "bem desenhada". ${ }^{3}$

Como professor e orientador, Jamary foi responsável pela formação de várias geraçóes de alunos que passaram pela Escola de Música da UFBA. Por um lado, um professor exigente, de meticulosa organização e austera disciplina, e, por outro lado, um orientador motivador, instigador e de cuidadoso suporte a cada um dos seus alunos, identificando sempre as demandas, velocidades e necessidades de cada um. Sempre atento à profundidade e à natureza dos pequenos detalhes, fazia de suas aulas uma imensa fonte de referências e direcionamentos, bem como entendia magistralmente o que cada aluno precisava. Para ele mesmo, porém, apenas "um aprendiz". ${ }^{4}$

O compositor e o professor se fundiram no pesquisador Jamary Oliveira. Muitas foram suas contribuições neste campo, quer seja nos programas que desenvolveu na área da Informática em Música, bem como na procura por respostas a questóes analíticas em música. Publicou inúmeros artigos, nos quais sua lucidez de pensamento e apurado rigor científico estâo perpetuados em valiosas fontes formativas.

Pessoalmente tive a honra e o privilégio de estudar com Jamary na graduação, no Mestrado e no Doutorado realizados na UFBA. Guardo carinhosamente as memórias de suas aulas. A diligência, a concisão, a lucidez na orientação são marcas que impactaram fortemente minha formação, e que hoje se desdobram na minha atividade como músico, como pesquisador e especialmente como professor. Em novembro de 2014, a Academia Brasileira de Música e a UFBA realizaram um evento/concerto em homenagem a Jamary pelos seus 70 anos, que tive a alegria de participar como performer e ajudando na organização.

$1 \quad$ Behague, Gerard. "Oliveira, Jamary" in Grove Music Online. Acessado em 17 de julho de 2020.

2 Oliveira, Jamary. Simplicidade: Três exemplos complexos ou Complexidade: Três exemplos simples. VII Encontro Anual da ANPPOM. São Paulo, 1994. In http://www.manuka.com.br. Acessado em 17 de julho de 2020 .

3 Informaçáo obtida a partir de entrevista realizada por Hugo Leonardo Ribeiro (Salvador, Junho de 1999).

4 Ibid. 
Nestes últimos tempos, tive em Jamary um amigo conselheiro. Em muitas oportunidades, numa conversa ao telefone, num breve encontro em eventos acadêmicos, ou num café em sua casa, sempre encontrei um interlocutor cuidadoso, uma fonte de boas reflexôes, e invariavelmente um pensador que me instigou a considerar aspectos mais recônditos de cada matéria. Tudo isso, sempre, de forma leve e motivadora. Te sou muito grato Jamary!

Neste momento, enquanto Diretor da Escola de Música da UFBA, quero registrar o nosso reconhecimento e gratidáo em nome desta escola e da Universidade Federal da Bahia por toda a tua dedicação, disponibilidade e zelo. Agradeço pelas tantas inovaçóes, pela incansável luta pela formação de qualidade na área da música, pela influência positiva em tantos estudantes e colegas. Agradeço pelo sorriso sóbrio, pela sempre pronta palavra de desafio, incentivo e direcionamento. A Escola de Música da UFBA te é muito grata Prof. Jamary Oliveira!

Enfim, nestas poucas linhas que reuni sobre o querido Jamary, deixo que ele resuma, fazendo minhas as suas palavras:

O tempo se encarrega de modificar os fatos e as lembranças sobre os fatos. Não me excluo deste efeito do tempo, mesmo quando tenho certeza de minhas lembranças. ${ }^{5}$

Jamary, descanse em paz e tenha nossa eterna gratidão!

5 Oliveira, Jamary. "O Grupo de Compositores da Bahia e sua Declaração de Princípios" in Marcos Teóricos da Composição Contemporânea na UFBA, III - Oliveira, Cerqueira, Herrera, Biriotti e Vaz: a "Declaraçáo de Princípios dos Compositores da Bahia" em depoimentos. Ilza Nogueira, Org. Salvador: Universidade Federal da Bahia, 2007. 